\title{
Women's Micro-Enterprises: Factors Influencing Business Performance
}

\author{
Ainon Ramli \\ Faculty of Entrepreneurship and Business, Universiti Malaysia Kelantan, \\ City Campus, Pengkalan Chepa, 16100 Kota Bharu, Kelantan, Malaysia.

\section{Zeity Liziana Razali} \\ Faculty of Entrepreneurship and Business, Universiti Malaysia Kelantan, \\ City Campus, Pengkalan Chepa, 16100 Kota Bharu, Kelantan, Malaysia.
}

\begin{abstract}
Micro Enterprises have a significant role in contributing to the economic development of Malaysia. However, the enterprises increasingly face competition not only from the same business segment but also from small, medium, and large enterprises. The objective of this study is to analyse the impact of internal and external factors (internal factors: entrepreneurial traits and managerial skills; external factors: access to finance, use of information technology, marketing, availability of business infrastructures) towards women's micro-business performance in Kelantan, Malaysia. The study adopted a quantitative methodology and surveyed 100 women's micro-businesses using questionnaires. The study concluded that the internal factors of entrepreneurial traits and managerial skills highly influenced the performance of women's microenterprises. The study further revealed that external factors do not impact the performance of women's micro-enterprises in Kelantan, Malaysia.
\end{abstract}

Keywords: Women's micro-enterprises, internal factors, external factors, business performance.

\section{INTRODUCTION}

Micro and small entrepreneurs have been acknowledged by the world, because they play a very important part in the development of a country regardless of whether it is a developed or a developing country (see Cassells and Lewis 2011; Isa et al., 2008; Hairuddin et al., 2012; Rasiah, 2002). There is no specific definition for micro and small enterprises (MSEs) because the definition depends on many factors (Kushnir, 2010). In the Malaysian context, micro enterprises record sales turnover of less than RM300,000 or have less than 5 full-time employees. Small enterprises are those businesses with sales turnover from RM300,000 to RM15 million or those that have from 5 to 75 full-time employees across all sectors for both micro and small (SME Corp Malaysia, 2018).

The MSEs create job opportunity, alleviate poverty, act as a mechanism for development and distribution of growth, and they are some of the sources of innovation (see Aremu and Adeyemi, 2011; Jasra et al., 2011; Taiwo et al., 2012). They improve the economic and social development of a country and they make big contributions to the market by offering many employment opportunities and big investments; also, they promote skill development and innovation (Liedholm, 2002).

Micro, small and medium-sized enterprises are contributing a lot to the economic development of Malaysia. This can be seen through the statistics provided by the SME Corp Malaysia (2018). In 2016, the number of these established enterprises was 907,065 (98.5\% of all enterprises) compared to the number established large firms which was only $13,559(1.5 \%)$. The report 
also showed that the number of them established in Malaysia from 2010 to 2015 grew at an average rate of $7.3 \%$ per annum.

Most of the enterprises are owned by men, and women owned enterprises are scarce. This current study only focused on women's micro-businesses located in Kelantan, Malaysia, which has been disregarded before. Looking further into the definition for women-owned enterprises specifically in Malaysia, it can be defined as the firms where women hold at least $51 \%$ of the equity, or the CEOs are women that own at least 10\% of the equity (SME Corp Malaysia, 2018).

\section{PROBLEM STATEMENT}

On a global scale, MSEs are the engines for entrepreneurial development that generate a broad spectrum of economic activities such as expanding employment opportunities and increasing the Gross Domestic Product (GDP). Also, they contribute significantly to the country's export trade sector. Micro, small, and medium sized enterprises are the backbone of Malaysia's economy (SME Corp Malaysia, 2018).

According to the Total Early-Stage Entrepreneurial Activity (TEA) report of Malaysia, in the year 2015 only $2.9 \%$ of businesses were in the starting process or were a newly run business compared to 2014 (5.9\%) and 2013 (6.6\%) (SME Corp Malaysia, 2016b). In spite of finance and physical infrastructure offered as compared to other regions in Asia Pacific and South Asia, the Global Entrepreneurship Monitor (2010) reported that Malaysia is the country before Japan that has the lowest TEA rate. The report also remarks that Malaysia is among the countries with the lowest proportion of people that have an intention to start a business and with entrepreneurs that have optimistic attitudes about entrepreneurship.

The failure rate of micro, small, and medium enterprises is surprising as $60 \%$ of businesses fail to survive (Ahmad and Seet, 2009). Based on the Census of Establishments and Enterprises 2011 by the Department of Statistics Malaysia (2011), 55.2\% of them found it difficult to obtain financing due to lack of collateral. Often, these companies failed because they did not have the correct business model or proper knowledge or they lacked focus and were too ambitious (Naylor, 2017). However, notwithstanding the failure issues, there were 645,136 micro, small and medium enterprises in Malaysia in 2010; this increased to 907,065 in 2015 (SME Corp Malaysia, 2016a). Although the overall rate of establishment of these sized enterprises in Malaysia are showing positive growth, the rates of these establishments in Kelantan are facing a negative downturn with 5.9\% in 2011 and dropping to 5.1\% in 2015 (SME Corp Malaysia, 2016a).

There are an increasing number of women starting to become involved in the small and medium enterprise (SMEs) sector. In 2015, there were186,930 enterprises or about $20.6 \%$ of the total of micro, small and medium enterprises in Malaysia that were owned by women (SME Corp Malaysia, 2016a). Supporting the global trends, the collective involvement of women in the SMEs is higher (Drine and Grach, 2012) because of various reasons that are pushing the women to start a business and to be self-employed rather than to be employed by others. In addition, the study found that the biggest reason is due to family matters which require the women to earn extra money in order to support their families and to provide a better living. Apart from that, the same researcher also added that child-care issues and the flexible working hours that being self-employed offers are a some of the reasons for women to be a part of the business world (Drine and Grach, 2012).

On the other hand, although the numbers of SMEs owned by women are increasing, the number of the successful micro, small and medium enterprises owned by women are small as 
it is hard to sustain success in the business world (Bowen et al., 2009; Fatoki, 2014). Based on those studies, this situation is due to several internal and external factors such as lack of funding or capital, low infrastructure, lack of marketing, or lack of managerial skills and experience.

In addition, according to the Organisation for Economic Cooperation and Development (1997), women owned businesses tend to have a higher failure rate in comparison to those businesses owned by men. Referring to the same report, this phenomenon is due to the nature of businesses chosen by women and poor management.

Kelantan is famous for its culture of high involvement of women in business (Norhaiyati et al., 2011). According to them, Kelantan women are known for their independence and they are proactive entrepreneurs who enthusiastically engage in business more than men. Thus, it is easy to find a business owned by women at the local market places in Kelantan. This shows that women are contributing to the economy of this state. In regards to the high amount of involvement of women in business, it is crucial to study the factors that influence the performance of MSEs owned by women in Kelantan.

There are several studies that investigate the relationship between the factors that affect micro, small and medium enterprise performance (see Mulugeta, 2014; Nasip et al., 2015; Wiklund and Shepherd, 2005). While some other studies looked at women owned business (see Satyajit et al., 2017; Wube, 2010). However, there is a paucity of studies about the performance of the MSEs owned by women especially in Malaysia and specifically in Kelantan. Thus, the main objective of this study is to examine the impact of selected factors on women's micro business performance.

\section{LITERATURE REVIEW}

Micro and small enterprises (MSEs) are considered to be the most important and they dominate the world economies (Wiklund and Shepherd, 2005). MSEs make big contributions to improve a country's economic and social development, whereby they produce employment opportunities and promote good entrepreneurship; also, they are innovative, develop home grown skills, and build a different scale of industrial base (Liedholm, 2002). Studies about small business's activities are increasing each day and they include government's role and policy makers who assist the small firms in expanding their business (Hill and McGowan, 1999). By studying this subject matter, the government and the policy makers can help the business develop. While in the meantime, small businesses can increase the employment rate of the country and promote innovation and healthy economic development (Dalrymple, 2004). This study is looking at the internal and external factors that contribute to women business success in Kelantan, Malaysia

\section{Women in Business}

There are various explanations for women's involvement in business activities and one of the reasons is to support their family's income (Hoe et al., 2012). Also, according to the study, they want to be independent, they are very disciplined, and they can set their working hours on their own. The study concludes that the women feel more comfortable in venturing into business because working time is flexible.

There are some characteristics of a successful woman such as independence, confidence, creativity and innovation (Forson and Özbilgin, 2003). These characteristics can be learned and developed as time goes by. The same study promotes that an additional influencing factor 
is that the women want is to be independent from the traditional dominant figure of the opposite sex and to overcome the boundaries of the severe structure of hierarchy in the corporate world.

The main limitations of women owned businesses are a lack of knowledge in business, the difficulty of getting loans, male domination problems (where men hold a sceptical view of women's business activities), and anxiety about sexual harassment (Alam, 2015). The study found that lack of knowledge and education are the women's biggest obstacles in business.

Women entrepreneurs are contributing to the development of entrepreneurship (Vujicic et al., 2013) which can be seen by the increasing number of businesses owned by women in developing countries. Thus, it is crucial to help and support this group to expand their businesses and to provide them with a better environment. Many women choose to venture into fields which require few skills, little labour, and little capital and areas with low complexity and low risk (Hoe et al., 2012). Thus, there are many women entrepreneurs involved in unpretentious business activities such as hawker, retail business, and wholesale business because these only require the entrepreneurs to have simple and basic information and technology.

Research that is related to businesses owned by women in Malaysia, a developing country, is still lacking in comparison to developed countries such as the United States and the United Kingdom. Thus, it is hard to understand the requirements, needs, and the problems that these woman entrepreneurs are facing in developing countries rather than the developed countries (Allen and Truman, 2016).

\section{Performance of MSEs}

In previous studies, the definition of performance may vary. Njanja and Ogutu (2010) defined performance in terms of the output of a business; for example, in terms of the number of objectives that a firm achieves or the measurement of the profit of a business. Alasadi and Abdelrahim (2007) claimed that successful performance of a business is where a business has adequate profit and financial growth resulting from increasing profit. Pagura (2003) found that poor business performance will lead a partner to drop out. The success level of a firm can be related to the performance of a firm. A study by Jones (1999) on the internalization process of small enterprises showed that firms that are small but well equipped with high technology are considered to be the most successful firms in comparison to other firms who do not have high technology equipment in doing their business. The performance of a business has been a prominent study that attracts many researchers to study these aspects in terms of small business (John, 2009).

The Malaysian SMEs are facing many challenges as highlighted by Ting (2004). The key challenges include problems with getting funding, limitations in human resource, restrictions or incompetence in embracing technology, absence of information on potential markets and customers, and global rivalry. According to him, the SMEs are facing high risks which require them to increase their competitiveness in order to stay in the rapidly changing market that strives for globalization.

\section{Access to Finance}

Nabintu (2013) found that in Kenya, SMEs were forced to develop a business using selffinancing or they have to borrow from their friends and relatives. This has resulted in business activities that cannot be pursued at their best. A previous study (Ageba and Amha, 2006) shows that there were a huge number ( $93 \%$ of the respondents) of MSEs who were reluctant 
to apply for bank loans because they think that they will fail to get a loan. This is due to the difficult process of borrowing, a high mortgage requirement, high interest rates, eligibility concerns, repayment ability concerns and, most of all, lack of information on borrowing. Gebreeyesus (2007) found that, 85\% of the respondents from his study did not acquire a credit loan from formal institutions due to lack of support from banks towards MSEs. Thus, the study concluded that the MSEs tend to get a loan from informal sources such as friends and relatives to fund their business.

Keyser et al. (2000) found that there were only 24\% of SME respondents in Zambia who have received a credit loan for their business start-up and this leads to the problem of lack of starting capital. A study by Koop et al. (2000) shows a positive and significant relationship between starting capital and business performance. Previous studies (see Daniels, 2003; Eeden, 2004) agreed that many SMEs face financial problems which include absence of information on how to get financing, restrictive borrowing offered by commercial banks, limited access to finance, inadequate financing, insufficient support documents required by the banks, limited access to collateral, and the fact that financial institutions lack appropriate structure for dealing with SMEs.

\section{Information Technology}

SMEs with innovation of technology have higher performance compared to SMEs that do not have it (Subrahmanya et al., 2010). More recently, a study by Apulu and Latham (2011) claimed that adoption of information and communication technology in business will increase the competitiveness of the SMEs. Lack of technological capabilities is the primary reason for the slow growth of the small businesses in developing countries (Arinaitwe, 2006). Despite the great technology advancements throughout the world, small businesses are still caught up with the problem of lack of implementation of technology in their business operation. Singh, Garg and Deshmukh (2009) found that many SMEs in India are in low scale production, this decreases their capability to have technology improvements, which is one of the major obstacles to SMEs growth. Small firms face a lot of barriers in the adoption of technology such as expensive hardware and software, lack of internet and ICT professionals and so on, which interferes with their progresses (Ssewanyana and Busler, 2007).

In the Malaysian context, the adoption of technology is important to SMEs (Abdullah, 2002). A study by Nasip et al. (2015) shows that technology is important for the sustainability of SMEs and it has a direct effect on the performance of the SMEs. Lo et al. (2009) studied 85 manufacturing companies located in Sarawak, Malaysia and concluded that there is a positive and significant relationship between a firm's performance and information technology. However, another study which surveyed 383 SMEs indicated that SMEs owners IT skills levels are low and usage of the internet in their workplace is rare (Hashim, 2015).

\section{Marketing}

Marketing strategy is important for a business to attain its objectives and goals (Li and Calantone, 1998). Marketing strategy is a set of marketing tools that firms use to pursue marketing objectives in their target market (Grönroos, 1999). A focus on the firm's synergies and resources are part of a marketing strategy (Keetch, 2009). Prior studies (see Owomoyela et al., 2013; Shoham, 2003; Theodosiou and Leonidou, 2003) proved that there is a relationship between business performance and marketing strategy.

Marketing skills are important to the SMEs owners as it is one of the factors that impacts business performance (Lussier and Pfeifer, 2001). According to Mulugeta (2014), marketing 
skills such as identifying new prospects, showing effective corporate positioning, customer handling, finding ways to efficiently advertise, and the ability to come up with new ideas are considered to be the most important factors for the SMEs in order to be successful for a long period. Pollard and Jemicz (2006) claimed that SMEs do not adopt marketing concepts as well as large firms, and this leads to the failure of SMEs in meeting their organizational goals. Dzisi and Ofosu (2014) found that marketing is one of the main practical strategies for the SMEs to adopt in order for them to improve their business performance. This is where the SMEs nowadays have realized the importance of the establishment of different strategies in order for them to understand the market, to serve their customers, and to compete with their competitors.

\section{Availability of Infrastructures}

One of the most critical factors in economic development is infrastructure because it is directly related to the economy of a country (Adenikinju, 2005). Muchie and Bekele (2009) found that the infrastructures for MSEs in Ethiopia are not reliable and are inefficient. The infrastructure factors such as electricity interruption and low service of transportation are hindering the MSEs performance (Abera, 2012). Even though the infrastructure factor is not the main factor that affects the growth of enterprises, the problems such as lack of water supply and lack of awareness of the importance of telephone and internet will lead to a negative effect on business performance (Wasihun and Paul, 2010). Obokoh and Goldman's (2016) findings shows that the lack of infrastructure has a negative effect on the profitability and performance of SMEs

Some of the MSE owners choose a place to start a business without studying the location infrastructure comprehensively (Mbonyane and Ladzani, 2011). Poor location of a facility will have a negative effect on the MSEs business performance (Olawale and Garwe, 2010). Waktola and Hirpha (2016) found that MSEs face a few major difficulties and one of them is inadequate infrastructure.

\section{Entrepreneurial Traits}

The success of a business may be due to several factors, but the utmost contributing factor for a successful business is the entrepreneur behind the business (Olakitan and Ayobami, 2011). Studies of the entrepreneurial traits in relation to business success are very limited (Baum et al., 2001). Hampel-Milagrosa et al. (2015) found that the MSEs located in the low- and middleincome countries are working hard to increase their performance and to establish themselves in order to become a medium or large size company. They claimed that other related studies are lacking in specific clarification on which factors contribute to the performance of the MSEs, which are either entrepreneurial factors or the characteristics of the firm, personal and business networks or the business environment factors. Entrepreneurial traits are the main factor for women entrepreneurs who are now being acknowledged as successful entrepreneurs (Satyajit et al., 2017). Entrepreneurial factors assist the conversion process of new ideas and concepts into novel products and services (Shane and Venkataraman, 2000). Entrepreneurship is viewed as an individual talent whereby it plays a vital part in the growth of human and intellectual capital (Zahra and Dess, 2001). There are a few fundamentals that are related to the entrepreneur culture and mind set such as entrepreneurial role models, presence of experienced entrepreneurs, skills and knowledge of the entrepreneurs, cultural attitudes towards entrepreneurship, and the proximity of entrepreneurial universities (Yusof, 2010). 


\section{Managerial Skills}

Bennett (1997) defines management as concerned with the deployment of material, human, and financial resources within the design of an organization structure. Meanwhile, Leonard and Hilgert (2007) state that management is a process of getting tasks accomplished with and through people by guiding and motivating their efforts. Rubin (2000) claimed that typical owners or managers of small businesses develop their own approach to management through a process of trial and error. The majority of SMEs owners come from a low educational background which makes them less fit to conduct managerial activities (King and McGrath, 2002). Tim and Brinkerhoff (2008) suggested that human capital is the most important instrument in determining an SMEs performance. Worku (2009) found in his study that a failed firm is caused by a manager who is deficient in the experience and knowledge needed to run a business. Professional experience is the most important determinant that has a big impact on many aspects of the SMEs (Brink et al., 2003). In addition, Marvel and Lumpkin (2007) agree that managerial experience is an important factor in motivating a firm's performance. A study regarding the long term survival of small businesses was conducted by Worku (2009) and one of the main contributing factors was the efficiency of management. The result of the research shows that a great manager with a high level of managerial skills stimulates profitability and continuity of the businesses.

The above discussion of previous studies helps to develop the following model that is illustrated in Figure 1.

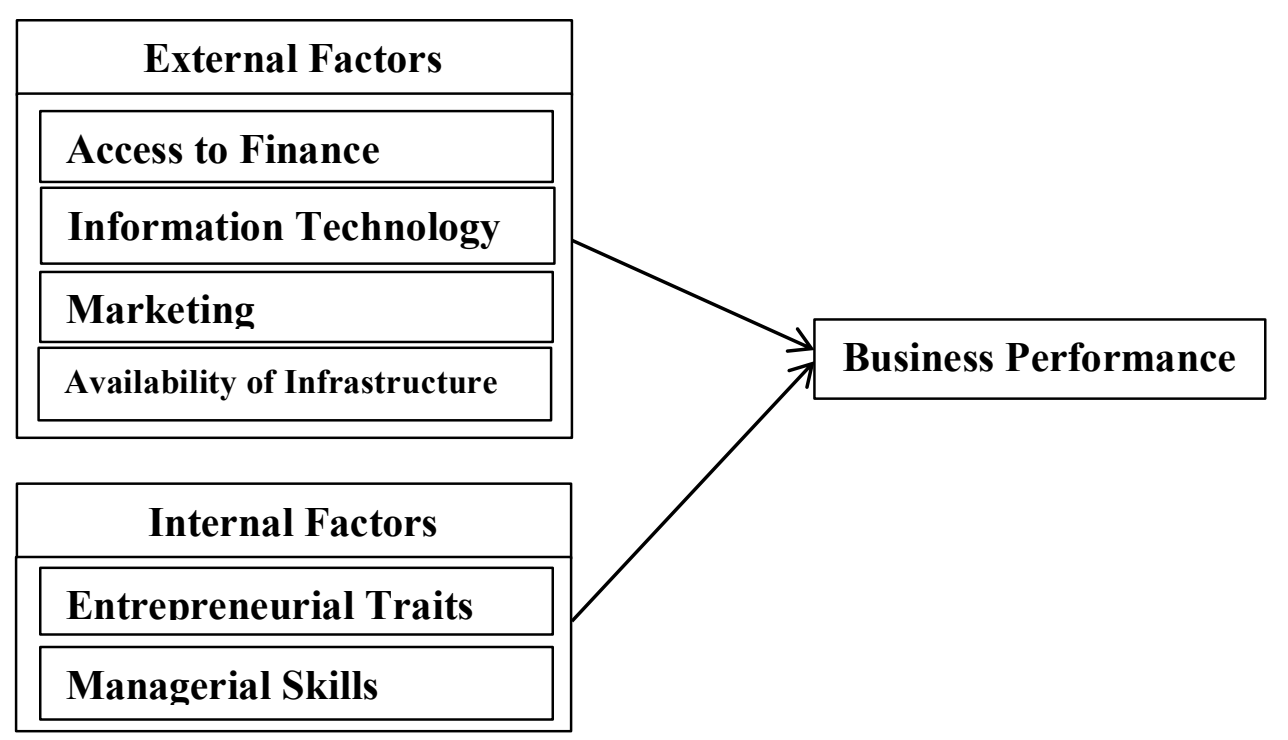

Figure 1: Conceptual framework of the study

\section{METHODOLOGY}

This current study uses an empirical approach focusing on a quantitative methodology. By implementing a quantitative approach, the relationship between success factors and firm performance can be exposed. The total population for micro, small and medium enterprises in Kelantan is about 46,000 (SME Corp Malaysia, 2018). The actual number of women owned micro businesses in Kelantan is unknown. The questionnaire has three sections. The content of Section A is about the demographic profile of respondents. Section B is about internal factors of entrepreneurial traits and managerial skills, and external factors: access to finance, use of information technology, marketing, and availability of business infrastructures. Section C asks about business performance, looking at the growth of the micro businesses. This study chooses Kota Bharu and Rantau Panjang districts to represent of the entire micro, small and medium 
enterprise populations in Kelantan. The two chosen districts are well-known as a business centre in the state of Kelantan. From the total population, 400 targeted respondents were sampled for the study, however, only 113 questionnaires were returned. After the data cleanup, only 100 data used for the final analysis using SPSS version 24.

\section{Respondents Profile}

\section{FINDINGS}

Table 1: Respondents Profile

\begin{tabular}{|c|c|c|c|c|c|c|c|c|}
\hline Age & $\mathrm{N}$ & $\%$ & Race & $\mathrm{N}$ & $\%$ & Education level & $\mathrm{N}$ & $\%$ \\
\hline Below 30 & 27 & 27 & Malay & 96 & 96 & $\begin{array}{l}\text { PMR/SRP(secondary } \\
\text { school level 1) }\end{array}$ & 5 & 5 \\
\hline $31-40$ & 32 & 32 & Chinese & 1 & 1 & $\begin{array}{l}\text { SPM/STAM(secondary } \\
\text { school level 2) }\end{array}$ & 48 & 48 \\
\hline $41-50$ & 22 & 22 & Others & 3 & 3 & Matriculation/Diploma & 32 & 32 \\
\hline Above 51 & 19 & 19 & Total & 100 & 100 & Degree & 12 & 12 \\
\hline \multirow[t]{2}{*}{ Total } & 100 & 100 & & & & Others & 3 & 3 \\
\hline & & & & & & Total & 100 & 100 \\
\hline $\begin{array}{l}\text { No. of years in } \\
\text { business }\end{array}$ & $\mathrm{N}$ & $\%$ & $\begin{array}{l}\text { No. of full-time } \\
\text { employee(s) } \\
\text { including owner }\end{array}$ & $\mathrm{N}$ & $\%$ & $\begin{array}{c}\text { No. of part-time } \\
\text { employee(s) including } \\
\text { owner }\end{array}$ & $\mathrm{N}$ & $\%$ \\
\hline Less than 1 & 9 & 9 & 1 & 59 & 59 & 0 & 81 & 81 \\
\hline $1-3$ & 21 & 21 & $2-3$ & 34 & 34 & 1 & 19 & 19 \\
\hline $4-6$ & 17 & 17 & $4-5$ & 7 & 7 & 2 & 0 & 0 \\
\hline $7-10$ & 21 & 21 & More than 5 & 0 & 0 & 3 & 0 & 0 \\
\hline More than 10 & 32 & 32 & Total & 100 & 100 & Total & 100 & 100 \\
\hline Total & 100 & 100 & & & & & & \\
\hline Type of business & $\mathrm{N}$ & $\%$ & $\begin{array}{l}\text { No. of } \\
\text { product(s)/ } \\
\text { service(s) }\end{array}$ & $\mathrm{N}$ & $\%$ & Estimated daily income & $\mathrm{N}$ & $\%$ \\
\hline Product & 85 & 85 & 1 & 55 & 55 & Below RM100 & 48 & 48 \\
\hline Service & 15 & 15 & $2-3$ & 27 & 27 & RM101-RM200 & 27 & 27 \\
\hline \multirow[t]{5}{*}{ Total } & 100 & 100 & $4-5$ & 18 & 18 & RM 201-RM300 & 16 & 16 \\
\hline & & & More than 5 & 0 & 0 & RM301-RM400 & 7 & 7 \\
\hline & & & Total & 100 & 100 & RM401-RM500 & 2 & 2 \\
\hline & & & & & & Above RM500 & 0 & 0 \\
\hline & & & & & & Total & 100 & 100 \\
\hline
\end{tabular}

Refering to Table 1 , from the total of 100 respondents, there were $27 \%$ of young entrepreneurs at the age of 30 or below, $32 \%$ at the age of 31 to 40 , and $19 \%$ of the total respondents were above 51 years old. The results show that young women in Kelantan are interested in business, however this was not shocking as women entrepreneurs are common in Kelatan (Zamzuraidah and Widad, 2004). From the total respondents, 96\% were Malays, 1\% Chinese and 3\% represent other races (Indonesian, Cambodian, and Siamese from Thailand). The majority of 
the respondents have completed their secondary school level 2 (48\%), about 32\% hold diplomas, and only $12 \%$ have completed a bachelor's degree.

Table 1 also shows that 32\% of the women's micro-businesses were founded more than ten years ago and $21 \%$ were in business between seven to ten years, which suggests that most of them were mature businesses. Of the total respondents, $59 \%$ of them were run by the owners themselves without any assistant, followed by 34\% who received help from one to two fulltime workers. Only $19 \%$ of the women entrepreneurs employed one worker on a part-time basis. The majority (85\%) of the businesses sold products and the balance (15\%) offered services to their customers. The results revealed that, $17 \%$ of the respondents only have one type of product or service in the business, while $23 \%$ have a range of two to three types of products or services offered. The highest percentage is $35 \%$ with a range of four to five types of products or services and $25 \%$ offered more than five types of products or services to the customers. They were asked to estimate their daily incomes with the majority of them earning RM100 or below (48\%) and less than $10 \%$ making more than RM300 a day.

\section{Test of Relationships}

\section{Preliminary Analysis of Correction}

The strength and direction of the linear relationship between variables can be described using the Pearson product-moment correlation coefficient where a small correlation value is between 0.10 and 0.29 , medium is around 0.30 to 0.49 and the large correlation value is between 0.50 and 1.0 (Pallant, 2013). The analysis is meant to check the relationship between six of the independent variables with a dependent variable. Pallant (2013) suggested some relationship of 0.30 and above. The value is either positive or negative and a positive value shows a positive relationship, a negative value shows a negative relationship, and 0 shows no relationship.

Table 2: Correlation Coefficient.

\begin{tabular}{|c|c|c|c|c|c|c|c|}
\hline & $\begin{array}{c}\text { Access } \\
\text { to } \\
\text { Finance } \\
\end{array}$ & $\begin{array}{l}\text { Information } \\
\text { Technology }\end{array}$ & Marketing & $\begin{array}{l}\text { Availability of } \\
\text { Infrastructure }\end{array}$ & $\begin{array}{c}\text { Entrepreneurial } \\
\text { Traits }\end{array}$ & $\begin{array}{l}\text { Managerial } \\
\text { Skills }\end{array}$ & Performance \\
\hline $\begin{array}{l}\text { Access to } \\
\text { Finance }\end{array}$ & 1 & $0.317^{* *}$ & $0.526^{* *}$ & $0.250^{*}$ & $0.445^{* *}$ & 0.159 & $0.386^{* *}$ \\
\hline $\begin{array}{l}\text { Information } \\
\text { Technology }\end{array}$ & $0.317^{* *}$ & 1 & $0.461^{* *}$ & $0.431^{* *}$ & $0.642^{* *}$ & $0.533^{* *}$ & $0.515^{* *}$ \\
\hline Marketing & $0.526^{* *}$ & $0.461^{* *}$ & 1 & $0.557^{* *}$ & $0.660^{* *}$ & $0.433^{* *}$ & $0.532^{* *}$ \\
\hline $\begin{array}{l}\text { Availability of } \\
\text { Infrastructure }\end{array}$ & $0.250^{*}$ & $0.431^{* *}$ & $0.557^{* *}$ & 1 & $0.541^{* *}$ & $0.410^{* *}$ & $0.451^{* *}$ \\
\hline $\begin{array}{l}\text { Entrepreneurial } \\
\text { Traits }\end{array}$ & $0.445^{* *}$ & $0.642^{* *}$ & $0.660^{* *}$ & $0.541^{* *}$ & 1 & $0.560^{* *}$ & $0.654^{* *}$ \\
\hline $\begin{array}{l}\text { Managerial } \\
\text { Skills }\end{array}$ & 0.159 & $0.533^{* *}$ & $0.433^{* *}$ & $0.410^{* *}$ & $0.560^{* *}$ & 1 & $0.641^{* *}$ \\
\hline Performance & $0.386^{* *}$ & $0.515^{* *}$ & $0.532^{* *}$ & $0.451^{* *}$ & $0.654^{* *}$ & $0.641^{* *}$ & 1 \\
\hline
\end{tabular}

Referring to table 2, all independent variables have positive and significant relationships with the dependent variable. Access to finance has the lowest relationship with performance (medium correlation value of 0.386$)$, followed by infrastructure (0.451). Other independent variables have a strong relationship with performance (values above 0.50). The test between each independent variable is also done to ensure that the value of relationships do not reach 0.70 and above in the same analysis (Pallant, 2013). In the results presented here, the highest 
correlation is 0.660 between entrepreneurial traits and marketing. Thus, all variables are retained.

\section{Test of Reliability}

The Cronbach alpha coefficient was used to measure the reliability scale from the collected data. DeVellis (2003) suggested that the value of a Cronbach alpha coefficient must be above 0.70. Pallant (2013) claimed that a Cronbach alpha value above 0.70 is adequate but a value above 0.80 is better. Based on table 3, the Cronbach alphas for all of the variables are above 0.70 except for access to finance. Thus, access to finance will be eliminated from further tests. The highest value can be seen in information technology of 0.882 .

Table 3: Cronbach Alpha

\begin{tabular}{|l|c|c|}
\hline Variables & Items & Cronbach's Alpha \\
\hline Access to Finance & 5 & 0.536 \\
\hline Information Technology & 5 & 0.882 \\
\hline Marketing & 5 & 0.745 \\
\hline Availability of Infrastructure & 5 & 0.700 \\
\hline Entrepreneurial Traits & 5 & 0.810 \\
\hline Managerial Skills & 5 & 0.803 \\
\hline Performance & 5 & 0.787 \\
\hline
\end{tabular}

\section{Regression Analysis}

The results from figure 2 below show that the beta path co-efficient between information technology and business performance is positive but insignificant $(\beta=0.038 ; t=0.403)$. The co-efficient originating from marketing is positive and also statistically insignificant to performance $(\beta=0.118 ; t=1.215)$. The results also show a positive but a statistically insignificant relationship between availability of infrastructure and performance $(\beta=0.042 ; \mathrm{t}=$ 0.484). In terms of entrepreneurial traits, the co-efficient linking the construct with performance is positive and statistically significant at $p$-value $0.05(\beta=0.320 ; t=2.861)$. Finally, the relationship between managerial skills and business performance is the strongest and it is positive and statistically significant with $p$-value $0.01(\beta=0.373 ; t=4.264)$. All the five constructs in the study explained $55 \%$ of the variance in business performance.

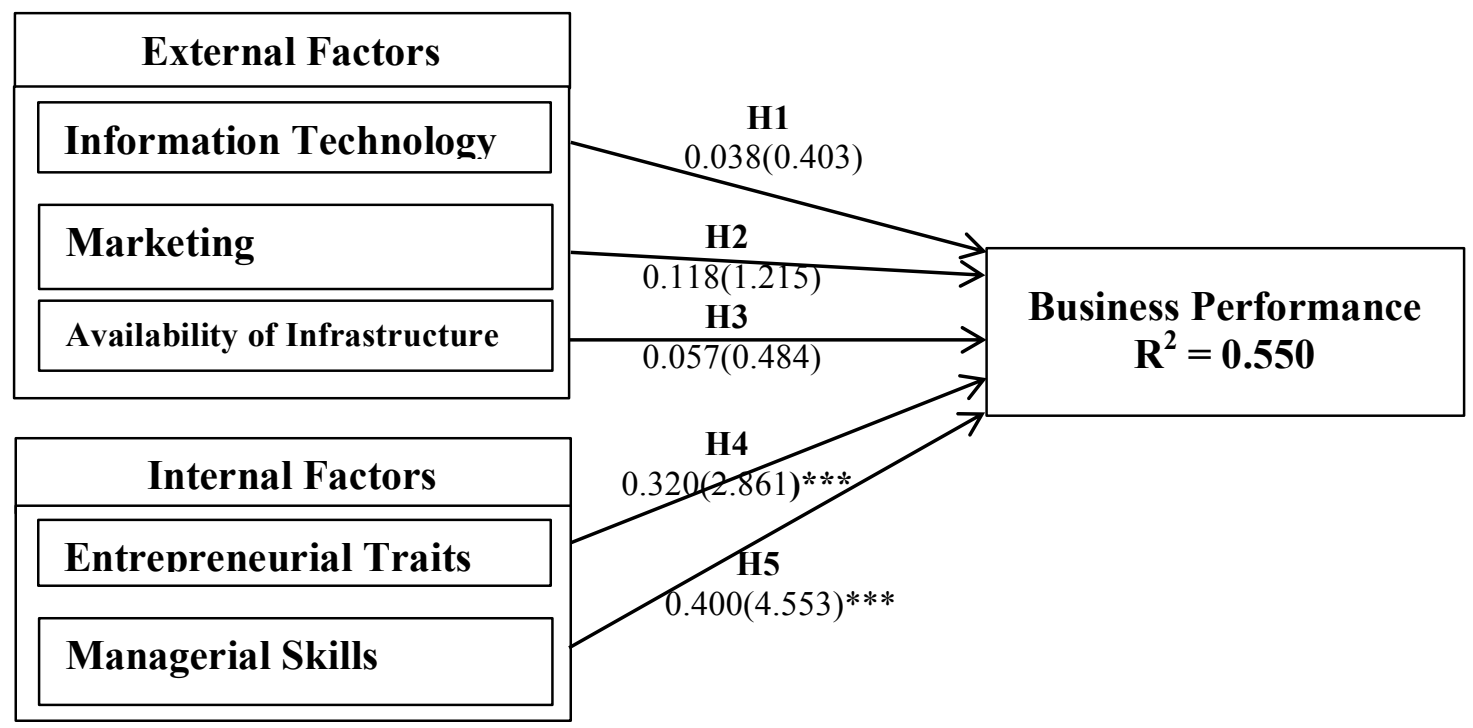

Figure 2: Results of Multiple Regression Analysis

*** significant at $\mathrm{p}$-value $<0.01{ }^{* *}$ significant at $\mathrm{p}$-value $<0.05$ :

$*$ significant at $\mathrm{p}$-value $<0.10$ 


\section{DISCUSSION AND CONCLUSION}

This study looked at six independent variables that affect the performance of women owned micro enterprises and they were access to finance, information technology, marketing, availability of infrastructure, entrepreneurial traits, and managerial skills. The access to finance correlation coefficient is significant at 0.01 level $(r=0.386)$. However, the Cronbach alpha value is only 0.536, which is below 0.70 and thus not reliable (DeVellis, 2003). It has been removed from further analysis.

The use of information technology in the business of women's micro-businesses in Kelantan shows insignificant results for impacting their business performance. The result is not consistent with the previous studies (see Bouazza et al., 2015; Ombongi and Long, 2018). Romijn (2001) concluded that information technology is important in order for the SMEs to strengthen their business and to stay competitive. Nonetheless, the insignificant result from this study for information technology has been acknowledged by a few previous researchers (see Mulugeta, 2014; Ramli and Taib, 2017). On the basis of a study by Mulugeta (2014), the use of information technology is low among the micro enterprises owned by women, so it does not significantly impact performance. The women who owned the micro enterprises are literally not into technological advance, so they are not willing to spend on information technology improvement for their business. They need to revalue the benefits and the advantages of information technology for their business because it may positively influence the business.

The impact of marketing towards performance is not significant in this current study. This is in contrast with the previous study by Mulugeta (2014) where the outcome of the study found that marketing had a strong positive correlation with performance and significantly affected the performance. Some other studies also reported significant results for marketing and performance (see Adenikinju, 2005; Muchie and Bekele, 2009; Obokoh and Goldman, 2016; Wasihun and Paul, 2010). Marketing is not in women businesses consideration when doing business, while having a good relationship with customers is adequate to market their products. Although this study put forward that they do not value products and services marketing, it is essential to their business. Hence, they need to study the power of marketing in business to realise the impact of products and services marketing to the business.

In this study, the availability of infrastructure is also found not to have a significant impact on performance. This is consistent with a previous study by Kinyua (2014). On the other hand, other studies (see Obokoh and Goldman, 2016; Olawale and Garwe, 2010; Wahisun and Paul, 2010; Waktola and Hirpha, 2016) found that availability of infrastructure has a positive and significant effect on performance. Business infrastructure may not directly influence business performance, but women's micro-businesses should see its importance and provide a better infrastructure for customers in order to help expand the business.

The next finding is that entrepreneurial traits have a positive and significant influence on performance. This result is supported by Anggadwita and Mustafid (2014). The success of a business may be due to several factors, but among the biggest factors contributing to the success of women businesses in Kelantan are their entrepreneurial traits. They have talent in business and endeavour to at least remain in the business. They need to compete with other micro businesses owned by men and bigger sized businesses.

Managerial skills have the largest relationship and highest impact on the performance of women's micro-enterprises in Kelantan. Good management will lead to a healthy business 
performance which then leads to the expansion of the business. A positive and significant relationship is shown in the previous studies (Abera, 2012; Mulugeta, 2014). Likewise, according to Kinyua (2014) managerial skills have the potential to have a positive and significant effect on performance. Therefore, the management of the business is important in order for the business to succeed. A worthy manager with high managerial skills and experience may lead a business to high performance. Hence, proper planning, good coordination, and control of activities by a highly skilled manager is crucial for the performance of a business. Managerial skills that managers have will determine the condition and the endurance of a business. Thus, with good managerial skills it is possible for women's micro-businesses to go further and succeed in their business.

The $\mathrm{R}^{2}$ value is 0.550 which shows that the independent variables have $55 \%$ impact on the dependent variables. Another $45 \%$ of the variance is not recorded in this study and that may be explained by other factors.

\section{CONTRIBUTIONS OF THE STUDY}

Generally, the study provides parameters for the micro enterprises on the factors that contribute to the performance of women's micro-businesses. This study can be used by existing, new, and potential micro businesses. Based on the research that has been done, this study promotes a track of accomplishment as a guideline for the future researchers. There is a possibility for other researchers in the future to enlarge and view the scope of the study in a perspective that can result in a diversity of insights.

\section{CONCLUSION}

The study was conducted with the primary intention of assessing the factors that influence the performance of women's micro-enterprises in Kelantan. To be specific, the study is an attempt to evaluate the identified factors that influence the performance of micro businesses which are access to finance, information technology, marketing, availability of infrastructure, entrepreneurial traits, and managerial skills. As a result, the external factors of access to finance, information technology, marketing, and availability of infrastructure do not impact the performance of women's micro-enterprises in Kelantan. The internal factors of entrepreneurial traits and managerial skills highly influenced business performance.

This study recommends that micro enterprises focus on the entrepreneurial factors in the business to perform well. The owners, specifically the women, should have a clear task and job description for their business to better manage and maintain a good business performance. They need to identify and analyse entrepreneurial factors such as the characteristic of the firm, the business network, and the environmental factors in order to conduct the business. It is important for the micro business owner to have good managerial skills to cope with the business and to solve complex business problems that may arise. They should also have accountability in monitoring business activities and not fully rely on the employees to manage business operations. It is also important to identify the strengths and weaknesses of the business, to grab opportunities and to avoid threats that might harm the business. Furthermore, the government also plays a big role in helping women's micro-businesses by providing training to improve business knowledge.

\section{References}

Abdullah M.A (2002). An Overview of the Macroeconomic Contribution of SMEs in Malaysia. In: C. Harvie, et al (eds). The Role of SMEs in National Economices in East Asia Series 2.

Adenikinju, A. F. (2005). Analysis of the cost of infrastructure failures in a developing economy: The case of the electricity sector in Nigeria. Retrieved from https://ideas.repec.org/p/aer/rpaper/rp_148.html 
Ageba, G., \& Amha, W. (2006). Micro and Small Enterprises (MSEs) finance in Ethiopia: empirical evidence. Eastern Africa social science research review, 22(1), 63-86.

Ahmad, N. H., \& Seet, P.-S. (2009). Dissecting behaviours associated with business failure: A qualitative study of SME owners in Malaysia and Australia. Asian Social Science, 5(9), 98.

Alam, M. S. (2015). Women Involvement in Small-scale Business in Kota Bharu, Kelantan, Malaysia. Paper presented at 8th Asia-Pacific Business Research Conference, Kuala Lumpur.

Alasadi, R., \& Abdelrahim, A. (2007). Critical analysis and modelling of small business performance (Case Study: Syria). Journal of Asia Entrepreneurship and sustainability, 3(2), 1-131.

Allen, S., \& Truman, C. (2016). Women in business: Perspectives on women entrepreneurs: Routledge.

Anggadwita, G., \& Mustafid, Q. Y. (2014). Identification of factors influencing the performance of small medium enterprises (SMEs). Procedia-Social and Behavioral Sciences, 115, 415-423.

Apulu, I., \& Latham, A. (2011). Drivers for information and communication technology adoption: a case study of Nigerian small and medium sized enterprises. International Journal of Business and Management, 6(5), 51.

Aremu, M. A., \& Adeyemi, S. L. (2011). Small and medium scale enterprises as a survival strategy for employment generation in Nigeria. Journal of sustainable development, 4(1), 200.

Arinaitwe, S. K. (2006). Factors constraining the growth and survival of small scale businesses. A developing countries analysis. Journal of American Academy of Business, Cambridge, 8(2), 167-178.

Baum, J. R., Locke, E. A., \& Smith, K. G. (2001). A multidimensional model of venture growth. Academy of management journal, 44(2), 292-303.

Bennett, N. (1997). Analysing management for personal development: theory and practice. Professional development for educational management, 60-73.

Bouazza, A. B., Ardjouman, D., \& Abada, O. (2015). Establishing the factors affecting the growth of small and medium-sized enterprises in Algeria. American International journal of Social science, 4(2), 101-115.

Bowen, M., Morara, M., \& Mureithi, M. (2009). Management of business challenges among small and micro enterprises in Nairobi-Kenya. KCA journal of business management, 2(1).

Brink, A., Cant, M., \& Ligthelm, A. (2003). Problems experienced by small businesses in South Africa. Paper presented at the 16th Annual Conference of Small Enterprise Association of Australia and New Zealand.

Cassells, S., \& Lewis, K. (2011). SMEs and environmental responsibility: Do actions reflect attitudes? Corporate Social Responsibility and Environmental Management, vol. 18, no. 3, pp. 186-199.

Dalrymple, J. F. (2004). Performance measurement for SME growth: A business profile benchmarking approach. Paper presented at the Second World Conference on POM and 15th Annual POM Conference, Cancun, Mexico, April.

Daniels, L. (2003). Factors that influence the expansion of the microenterprise sector: results from three national surveys in Zimbabwe. Journal of International Development, 15(6), 675-692.

Department of Statistics Malaysia. (2010). Preliminary Count Report of Population and Housing Census Of Malaysia 2010.

Department of Statistics Malaysia. (2011). Census of Establishments and Enterprises: Department of Statistics Malaysia.

DeVellis, R. F. (2003). Scale development: Theory and applications. Applied social research methods series. Bickman, L and DJ Rog: Thousand Oaks, Calif.: SAGE Publications, Inc.

Drine, I., \& Grach, M. (2012). Supporting women entrepreneurs in Tunisia. The European Journal of Development Research, 24(3), 450-464.

Dzisi, S., \& Ofosu, D. (2014). Marketing strategies and the performance of SMEs in Ghana. European Journal of Business and Management, 6(5).

Eeden, S. (2004). Knowledge management for sustainable competitiveness in small and medium surveying practices. Structural Survey, 23(1), 7-21.

Fatoki, 0. (2014). The causes of the failure of new small and medium enterprises in South Africa. Mediterranean Journal of Social Sciences, 5(20), 922. 
Forson, C., \& Özbilgin, M. (2003). Dot-com women entrepreneurs in the UK. The International Journal of Entrepreneurship and Innovation, 4(1), 13-24.

Gebreeyesus, M. (2007). Growth of micro-enterprises: Empirical evidence from Ethiopia. Ethiopian Development Research Institute (EDRI), 1-21.

Grönroos, C. (1999). Relationship marketing: challenges for the organization. Journal of Business Research, 46(3), 327-335.

Hairuddin, H., Noor, N. L. M., \& Ab Malik, A. M. (2012). Why do microenterprise refuse to use information technology: A case of batik microenterprises in Malaysia. Procedia-Social and Behavioral Sciences, 57, pp. 494-502.

Hampel-Milagrosa, A., Loewe, M., \& Reeg, C. (2015). The entrepreneur makes a difference: Evidence on MSE upgrading factors from Egypt, India, and the Philippines. World Development, 66, 118-130.

Hashim, J. (2015). Information communication technology (ICT) adoption among SME owners in Malaysia. International Journal of Business and Information, 2(2).

Hill, J., \& McGowan, P. (1999). Small business and enterprise development: questions about research methodology. International Journal of Entrepreneurial Behavior \& Research, 5(1), 5-18.

Hoe, C. H., Isa, F. M., Hin, C. W., Hashim, N., Yunus, J. M., \& Abdullah, H. H. (2012). Development of women entrepreneurs: the case of Malaysia. World Journal of Social Sciences Vol. 2. No. 6. Pp. 123 - 145

Isa, C. R., Saleh, Z., \& Sapiei, N. S. (2008). A survey on financial and management accounting practices among Small and Medium Enterprises in Malaysia. Journal of Accounting Perspectives, vol. 1, iss. 1, pp. 13-25.

Jasra, J. M., Hunjra, A. I., Rehman, A. U., Azam, R. I., \& Khan, M. A. (2011). Determinants of business success of small and medium enterprises. International Journal of Business and Social Science, Vol. 2, No. 20, pp. 274-280

John, B. K. (2009). Assessing performance of micro and small scale Agribusinesses in Northern Ghana: NonFinancial and Stochastic frontier analysis. MBA Thesis, College of Agriculture and Natural Resources, Kwame Nkrumah University of Science and Technology, Ghana.

Jones, M. V. (1999). The internationalization of small high-technology firms. Journal of International marketing, $15-41$.

Keetch, P. (2009). The official guide to Marketing Strategy. Retrieved fromhttp://Ezine articles.com

Keyser, M., de Kruif, M., \& Frese, M. (2000). The psychological strategy process and sociodemographic variables as predictors of success for micro-and small-scale business owners in Zambia. In M. Frese (Ed.), Success and failure of microbusiness owners in Africa: A psychological approach (pp. 31-53). Westport, CT, US: Quorum Books/Greenwood Publishing Group.

King, K., \& McGrath, S. (2002). Globalisation, enterprise and knowledge: Education, training and development in Africa. Symposium, Oxford.

Kinyua, A. N. (2014). Factors affecting the performance of Small and Medium Enterprises in the Jua kali sector in Nakuru Town, Kenya. IOSR Journal of Business and Management (IOSR-JBM), 16(1), 80-93.

Koop, S., de Reu, T., \& Frese, M. (2000). Sociodemographic factors, entrepreneurial orientation, personal initiative, and environmental problems in Uganda. In M. Frese (Ed.), Success and failure of microbusiness owners in Africa: A psychological approach (pp. 55-76). Westport, CT, US: Quorum Books/Greenwood Publishing Group.Kushnir, K. (2010). A Universal Definition of Small Enterprise: A Procrustean bed for SMEs? Retrieved 28 April, 2018, from http://blogs.worldbank.org/psd/a-universal-definition-of-small-enterprise-a-procrustean-bed-for-smes

Kushnir, K. (2010). A Universal Definition of Small Enterprise: A Procrustean bed for SMEs? Retrieved 28 April, 2018, from http://blogs.worldbank.org/psd/a-universal-definition-of-small-enterprise-a-procrustean-bed-for$\underline{\text { smes }}$

Leonard, E. C., \& Hilgert, R. L. (2007). Supervision : concepts \& practices of management (10th ed ed.): Thomson/South-Western.

Li, T., \& Calantone, R. J. (1998). The impact of market knowledge competence on new product advantage: conceptualization and empirical examination. The Journal of Marketing, 13-29.

Liedholm, C. (2002). Small firm dynamics: evidence from Africa and Latin America. Small Firm Dynamism in East Asia (pp. 227-242): Springer.

Lo, M.-C., Mohamad, A. A., \& La, M. K. (2009). The relationship between human resource management and firm performance in Malaysia. International Journal of Economics and Finance, 1(1), 103. 
Lussier, R. N., \& Pfeifer, S. (2001). A crossnational prediction model for business success. Journal of Small Business Management, 39(3), 228-239.

Marvel, M. R., \& Lumpkin, G. T. (2007). Technology entrepreneurs' human capital and its effects on innovation radicalness. Entrepreneurship Theory and practice, 31(6), 807-828.

Mbonyane, B., \& Ladzani, W. (2011). Factors that hinder the growth of small businesses in South African townships. European Business Review, 23(6), 550-560.

Muchie, M., \& Bekele, E. (2009). Promoting micro, small and medium Enterprises (MSMEs) for sustainable rural Livelihood. Aalborg: Institut for Historie, Internationale Studier og Samfundsforhold, Aalborg Universitet.

Mulugeta, H. (2014). Assessing the Factors Affecting the Performance of Micro and Small Scale Enterprises: the Case of Yeka Sub-City, Addis Ababa. MBA thesis, St. Mary's University.

Nabintu, N. (2013). Factors affecting the performance of small and micro enterprises (smes) traders at city park hawkers market in Nairobi county, Kenya. Phd thesis, University of Nairobi.

Nasip, S., Hassan, R. A., \& Muda, N. N. (2015). Factors affecting the firm performance among small and medium sized enterprises (smes): a conceptual paper. Retrieved from www.ums.edu.my

Naylor, M. (2017). AmBank Bantu Bangunkan PKS. Retrieved from https://leaderonomics.com/bm/artikel/ambank-bangunkan-pks

Njanja, W., \& Ogutu, M. (2010). An Investigation into the Effect of Management Factors on Performance of (Micro, Small and Medium Enterprises) in Kenya. International Journal of Business and Management, 5(11), 66.

Norhaiyati, A., Nik, M., \& Md, W. (2011). The influential factors in decision-making process among Malay Women Entrepreneurs. The Institute for the Empowerment of Women Malaysia, Kuala Lumpur.

Obokoh, L. O., \& Goldman, G. (2016). Infrastructure deficiency and the performance of small- and medium-sized enterprises in Nigeria's Liberalised Economy. https://actacommercii.co.za/index.php/acta/article/view/339

Olakitan, O. O., \& Ayobami, A. P. (2011). An investigation of personality on entrepreneurial success'. Journal of Emerging Trends in Economics and Management Sciences, 2(2), 95-103.

Olawale, F., \& Garwe, D. (2010). Obstacles to the growth of new SMEs in South Africa: A principal component analysis approach. African journal of Business management, 4(5), 729.

Ombongi, P. N., \& Long, W. Factors Affecting Financial Performance of Small and Medium Enterprises (SMEs): A Case of Manufacturing SMEs in Kenya. International Journal of Research in Business Studies and Management Volume 5, Issue 1, 2018, PP 37-45

Organisation for Economic Cooperation and Development. (1997). Job Creation and Growth: Facts, Obstacles and Best Practices: OECD.

Owomoyela, S., Oyeniyi, K., \& Ola, O. (2013). Investigating the impact of marketing mix elements on consumer loyalty: An empirical study on Nigerian Breweries Plc. Interdisciplinary Journal of Contemporary Research in Business, 4(11), 485-496.

Pallant, J. (2013). SPSS survival manual: A step by step guide to data analysis using SPSS . Maidenhead: Open University Press/McGraw-Hill.

Pollard, D., \& Jemicz, M. (2006). Marketing deficiencies and the internationalization of Czech SMEs. International Journal of Entrepreneurship and Small Business, 3(3), 4.

Ramli, A., \& Taib, M. (2017). Malaysian Malay micro businesses: success factors in Langkawi Island. Sci.Int.,29(6),1191-1198.

Romijn, H. (2001). Technology support for small-scale industry in developing countries: a review of concepts and project practices. Oxford Development Studies, 29(1), 57-76.

Rubin, H. J. (2000). Renewing hope within neighborhoods of despair: The community-based development model: SUNY Press.

Satyajit, R., Priyanka, T., \& PK, T. (2017). Assessment of Factors Affecting the Performance of Women Entrepreneurs in MSE in Polosara District of Ganjam, Odisha. British Journal of Economics, Management \& Trade 17(3): 1-11, 2017.

Shane, S., \& Venkataraman, S. (2000). The promise of entrepreneurship as a field of research. Academy of management review, 25(1), 217-226. 
Shoham, A. (2003). Standardization of international strategy and export performance: A meta-analysis. Journal of Global Marketing, 16(1-2), 97-120.

Singh, R. K., Garg, S. K., \& Deshmukh, S. (2009). The competitiveness of SMEs in a globalized economy: Observations from China and India. Management Research Review, 33(1), 54-65.

SME Corp Malaysia. (2013). Guideline For New SME Definition. In S. t. t. N. S. D. Council (Ed.), (pp. 12): SMECORP. (Reprinted from: August 2016).

SME Corp Malaysia. (2016a). Economic Census 2016: SME Corporation Malaysia.

SME Corp Malaysia. (2016b). SME Annual Report 2015/2016.

Ssewanyana, J., \& Busler, M. (2007). Adoption and usage of ICT in developing countries: Case of Ugandan firms. International Journal of Education and Development using ICT, 3(3).

Subrahmanya, M., Mathirajan, M., \& Krishnaswamy, K. (2010). Importance of technological innovation for SME growth: Evidence from India: Working paper//World Institute for Development Economics Research.

Taiwo, M. A., Ayodeji, A. M., \& Yusuf, B. A. (2012). Impact of small and medium enterprises on economic growth and development. American journal of business and management, 1(1), 18-22.

Theodosiou, M., \& Leonidou, L. C. (2003). Standardization versus adaptation of international marketing strategy: an integrative assessment of the empirical research. International Business Review, 12(2), 141-171.

Tim, M., \& Brinkerhoff, R. (2008). Courageous Training: Bold Actions for Business Results. Colorado: BerrettKoehler Publishers.

Waktola, A. D., \& Hirpha, M. A. (2016). Analysis of the Main Cause for the Entrepreneurs Drop Out in Micro and Small Enterprises: Evidences from Nekemte Town, Eastern Wollega Zone, Oromia Regional State, Ethiopia. International Journal of Economics \& Management Sciences, 5(6)

Wasihun, R., \& Paul, I. (2010). Growth determinants of women operated micro and small enterprises in Addis Ababa. Journal of sustainable Development in Africa, 12(6), 233-246.

Wiklund, J., \& Shepherd, D. (2005). Entrepreneurial orientation and small business performance: a configurational approach. Journal of business venturing, 20(1), 71-91.

Worku, Z. (2009). Efficiency in management as a determinant of long-term survival in micro, small and medium enterprises in Ethiopia. Problems and Perspectives in Management, 7(3), 1-9.

Wube, M. C. (2010). Factors affecting the performance of women entrepreneurs in micro and small enterprises: the case of Dessie Town. Master Thesis, Department Of Educational Planning and Management, Bahir Dar University.

Yusof, S. N. W. M. (2010). Success factors in entrepreneurship : the case of Malaysia. Universitat Autonoma de Barcelona.

Zahra, S., \& Dess, G. G. (2001). Entrepreneurship as a field of research: Encouraging dialogue and debate. Academy of management review, 26(1), 8-10.

Zamzuraidah, I. and Widad, O. (2004). Faktor-faktor Yang Mendorong Usahawan Wanita kelantan Menceburi Bidang Perniagaan Di Pasar Siti khadijah Kelantan. http://merr.utm.my/id/eprint/9060 